\title{
Advantages And Shortcomings Of Korean Chaebols
}

Hong Y. Park, (Email: hyp@svsu.edu), Saginaw Valley State University Geon-Cheol Shin, (Email: gcshin@khu.ac.kr), Kyung Hee University, Korea Sung Hahn Suh, Kyung Hee University, Korea

\begin{abstract}
The prevalent form of business organizations in Korea is a chaebol. The chaebol is a diversified conglomerate. This paper addresses the following issues concerning Korean chaebols: 1) reasons for diversification, 2) advantages and shortcomings of chaebols, 3) issues facing Korean chaebols, and 4) chaebols' managing the crisis and making reforms. We found that Korean chaebols managed to learn from the economic crisis and made successful reforms.
\end{abstract}

\section{Introduction}

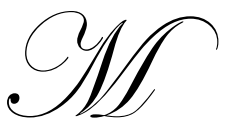

ost large Korean firms are diversified conglomerates (Jung and Yang, 1992). The four largest of which are Samsung, LG, Hyundai Motor and SK based on sales in 2004. Samsung is the largest in sales; 63 companies make up the Samsung group. LG consists of 46 companies; Hyundai Motor has 28, and 59 companies make up the SK group. Diversified conglomerates dubbed chaebol in Korea, are the prevalent form of business organizations. As Khanna and Rivkin (2001) point out, such business groups are more common in emerging economies than in advanced economies.

Studies on firms' product portfolios focus on the why, where and what of diversification. The why of diversification is to discover determinants of product diversification. Teece $(1980,1982)$ has summarized that transaction costs, excess resources and scope economies account for product diversification. Studies on the where of diversification focus on the direction of firms' product diversification. Numerous studies report that related diversification contributes to firms' profits more than unrelated product diversification (Barney, 1988; Caves, 1971; Gorecki, 1975; Rumelt; 1982: Teece et al., 1994). What are the impacts of diversification? Remelt's study (1982) shows that "the highest levels of profitability were exhibited by those having a strategy of diversifying primarily into those areas that drew on some common core skill or resource" (p.359). Montgomery and Wenerfelt (1988) drew a similar conclusion that the farther firms must go to use their factors, the lower the marginal rents they extract. Teece et al. (1994) also found that given tight selection environments, coherent diversification is the most common corporate diversification mode in the U.S. economy as well as in other countries, especially in Korea.

This paper will explore the reasons why Korean chaebols are diversifying; study advantages and shortcomings of Korean chaebols; and assess chaebols' dynamic capabilities of managing the economic crisis and making reforms. The forms of organization clearly matter in firms' performance (Brickley et al., 2007; Milgrom \& Roberts, 1992). Thus assessing advantages and shortcomings will offer clues to improve Korean chaebols. Survey data in our earlier study (Park \& Shin, 2004) provides the starting point for this analysis.

The paper consists of five sections. Section 2 briefly surveys the literature; section 3 provides the design of the survey and reports the survey results. We discuss the results in section 4 and present conclusions and implications in section 5 . 


\section{Literature}

Excess capacity of production factors is regarded as the most important determinant of firms' product diversification (Caves, 1971; Gorecki, 1975; Penrose, 1959; Teece, 1982). According to the excess capacity of resources, firms diversify in response to excess capacity of resources that are subject to market failure (Montgomery and Wernerfelt, 1988). The firm may decide to use the capacity internally, instead of selling or renting it in an imperfect factor market, and these circumstances lead to diversification (Montgomery and Wernerfelt, 1988; Williamson, 1985).

Transaction cost theory (Coase, 1937; Williamson, 1975, 1985) offers an answer to the question of why not all production is carried on by one big firm. According to Coase (1937), "a firm will tend to expand until the costs of organizing an extra transaction within the firm equal the costs of carrying out the same transaction by means of an exchange on the open market or the costs of organizing in another firm." Williamson $(1975,1985)$ indicated that volume, frequency, and asset specificity are determining factors of internal production or market. The frequent and large volume of production with a high degree of asset specificity leads to product diversification.

Scope economies (Chandler, 1990; Teece, 1980, 1982) give an advantage of diversification in production costs over the market. Our study investigates other factors of firms' product diversification that may be unique in Korean chaebols. Large Korean chaebols have the same proclivity of oligopoly. They tend to compete with each other. When one chaebol delves into a new business, other chaebols tend to rush into that business.

Chaebols may need to diversify to avoid declining profits in one industry. Schmalensee (1985) and Rumelt (1991) indicate that industry effects are the main sources of firm profitability. Demand growth in mature industries tends to be stagnant, so Korean chaebols typically expand in new and high-tech growth industries and diversify rather than exit from mature industries.

Since close family ties are the nature of Korean culture, owners of business firms try to give businesses to their children. These tendencies can also be a source of diversification in Korean chaebols.

Benefits and shortcomings stem from the nature of Korean chaebols. Benefits can be scale and scope economies, vast knowledge and experiences in diversified businesses, reputation and brand name. Some characteristics of chaebols are disadvantages because they are diversified.

Simon (1993) views the history of organizations in evolutionary terms. He states that each organization competes with others for scarce resources, and organizations' fates must consequently be decided by some combination of natural selection and rational adaptation.

\section{Designs And Conduct Of Survey}

Our study examines Korean chaebols' learning from the Korean economic crisis. The survey questionnaire was designed to create a better understanding of the nature of Korean chaebols and their improvement. We created a website for the questionnaire and asked managers to answer questions. Two-hundred four managers, representing the majority of large business groups in Korea and many other firms, responded to the survey. The questionnaire was designed for respondents to rank the top three items in the order of importance among the listed factors in each question. To avoid confusion in priority ranking we did not ask respondents to rank all items in each question.

\subsection{Reasons For Diversification}

The first survey question, regarding reasons for diversification, has designed to find out why Korean chaebols diversify. Weighting was used to signify the importance of each factor. Each factor's weighted total score was calculated by giving more weight to rank 1 than rank 2; more weight to rank 2 than rank 3 . For example, 36 respondents ranked chaebols' competition with each other as the most important reason for chaebols' diversification; 38 respondents ranked it as the second most important reason; and 79 respondents ranked it as the 
third most important reason. The total score for chaebols' diversification on competing with each other is 263 , which is obtained as follows:

$36 \times 3+38 \times 2+79 \times 1=263$

The rank of each factor is determined by the total score and Table 1 is the results of the survey on reasons for chaebols' diversification.

Diversification combines multiple business cycles from each product market, so lowering risk that is, smoothing out performance fluctuations (Salter and Weinhold, 1979). Diversification reduces the probability that a firm will experience lower performance, so firms make adaptive change to avoid performance fluctuations (Donaldson, 2000). The benefits of such financial portfolio diversification for individuals are well established and proved, diversifying the corporate product portfolio is not as well established. However survey results show that diversification to avoid risks has the highest survey responses.

Table 1: Reasons for Diversification

\begin{tabular}{|c|c|c|c|c|c|}
\hline \multirow{2}{*}{ Factors } & \multicolumn{5}{|c|}{ Responses } \\
\hline & 1 & 2 & 3 & Total & Rank \\
\hline To avoid the risk of a single product business & 88 & 61 & 34 & 420 & 1 \\
\hline $\begin{array}{l}\text { To participate in new businesses using new state of the art } \\
\text { technologies }\end{array}$ & 59 & 69 & 32 & 347 & 2 \\
\hline To compete with other chaebols & 36 & 38 & 79 & 263 & 3 \\
\hline To leave business as inheritance to children & 9 & 26 & 38 & 117 & 4 \\
\hline Others & 5 & 2 & 9 & 28 & 5 \\
\hline
\end{tabular}

Large chaebols such as Samsung, LG and SK all developed in new products using new technologies. For example, all three participated in telecommunication as it emerged. Samsung and LG are now second and third in market share of mobile phone sales. They also tend to show the oligopoly behavior of competition: if one large firm enters into a new field in business, others tend to follow the leader.

\subsection{Benefits Of Chaebols} respondents.

The survey question on benefits of chaebols included six items. Table 2 shows the survey results of

Table 2: Benefits of Chaebols

\begin{tabular}{|c|c|c|c|c|c|}
\hline \multirow{2}{*}{ Factors } & \multicolumn{5}{|c|}{ Responses } \\
\hline & 1 & 2 & 3 & Total & Rank \\
\hline $\begin{array}{l}\text { Easy diversification in businesses with established reputation, and } \\
\text { recognition of chaebols' brand name }\end{array}$ & 59 & 65 & 30 & 337 & 1 \\
\hline Scope economies by synergy effects & 71 & 36 & 40 & 325 & 2 \\
\hline Scale economies by large size & 33 & 35 & 37 & 206 & 3 \\
\hline $\begin{array}{l}\text { Improvements in decision making by having cumulated } \\
\text { knowledge and experiences of many companies in a chaebol }\end{array}$ & 15 & 35 & 35 & 150 & 4 \\
\hline $\begin{array}{l}\text { Improvements in capturing new business opportunities with vast } \\
\text { knowledge in many fields of business }\end{array}$ & 9 & 16 & 42 & 101 & 5 \\
\hline Other & 0 & 0 & 0 & 0 & 6 \\
\hline
\end{tabular}


Survey respondents ranked easy diversification due to chaebols' brand name reputation and recognition on the top. According to Caves (1980), brand name is an intangible asset and brand name resource does not deplete as the firm uses it more. This result, therefore, supports the excess resource theory of diversification.

Scores in scope and scale economies, 325 and 206 respectively, illustrate that diversified chaebols are well aware of the advantages of scope and scale economies. Chandler (1990) points out cost advantages due to U.S. business firms' scope and scale economies. Teece's (1982) paper on multiproducts of the firm shows the benefit of the scope economy of multiproducts.

Improvements in decision making with cumulated knowledge and experiences of corporate leaders in the chaebols gathered a significant number of responses. Improvements in capturing new business opportunities also show some significance. These two factors are benefits of chaebols because the chaebol form of business conglomerates engages in businesses across several industries. Chaebol decision making groups also have a wealth of knowledge and experience. The knowledge-based approach to the firm values highly the importance of knowledge and experiences (Barney, 1986; Grant, 1996; Knudsen, 1995; Nonaka and Takeuchi, 1995, Spencer, 1996).

\subsection{Shortcomings Of Chaebols}

The chaebol's organizational form has hazards as well as benefits. The negative aspects of chaebols need to be examined carefully to mitigate such hazards. The survey question designed to find out shortcomings of chaebols is informative.

Table 3: Shortcomings of Chaebols

\begin{tabular}{|c|c|c|c|c|c|}
\hline \multirow{2}{*}{ Factors } & \multicolumn{5}{|c|}{ Responses } \\
\hline & 1 & 2 & 3 & Total & Rank \\
\hline Lack of business transparency & 30 & 51 & 22 & 214 & 1 \\
\hline $\begin{array}{l}\text { High risks of businesses due to the CEO's autocratic decision- } \\
\text { making }\end{array}$ & 37 & 29 & 40 & 209 & 2 \\
\hline $\begin{array}{l}\text { Increase in exit costs by losing timely exit of unprofitable } \\
\text { businesses }\end{array}$ & 29 & 36 & 24 & 183 & 3 \\
\hline $\begin{array}{c}\text { Increase in management costs due to the bureaucratic } \\
\text { organization }\end{array}$ & 36 & 23 & 27 & 181 & 4 \\
\hline Inefficient resource allocation & 24 & 13 & 34 & 132 & 5 \\
\hline Lack of the timely decision making and adaptation & 23 & 22 & 17 & 130 & 6 \\
\hline Delay of development in core capabilities & 10 & 13 & 20 & 76 & 7 \\
\hline Other & 0 & 0 & 1 & 1 & 8 \\
\hline
\end{tabular}

As the survey indicates, one of the pressing problems in chaebols is the lack of business transparency. The information asymmetry problems are ubiquitous in today's business world. However, the unique problem stemming from asymmetric information in chaebols is the governance problem, since the top managers or CEOs in chaebols tend to be both owners and managers. They are different from the hired managers with a small stake in the company. Managers with relatively large ownership stake in diversified Korean chaebols often engage in expropriating the dispersed minority shareholders; the lack of transparency magnifies this expropriation.

The highly autocratic decision-making in chaebols is dubbed as 'imperialistic management' in the popular Korean press. This kind of management has adverse effects on corporate performance since managers do not fully utilize the knowledge and experiences of employees. However, the flip side of imperialistic management is that it may result in strong commitment to their favorite projects. It is a well-known fact that successes in Korean chaebols' telecommunication businesses are generated by CEOs' commitment of huge financial capital to research and development in semiconductor and telecommunication products. 
Chaebols' cross-subsidies often serve to prolong the lives of unprofitable businesses and delay their exits. These practices can be burdensome to the whole chaebol group. The costs caused by delayed exits led to collapses of several chaebols during the 1997 Korean economic crisis such as Dawwoo and Ssangyong.

Large organizations tend to be more bureaucratic and management costs rise as a result; significant numbers of respondents shared these concerns. Politics also play a role in large bureaucratic organization, and political decision making can result in inefficient resource allocation when bureaucratic organization loses timely decision making and adaptation to changing environments. These are shortcomings of the Korean chaebols.

\subsection{Issues Facing Korean Chaebols}

Korean chaebols confronted many issues during and after the 1997 economic crisis. Understanding the nature of the issues is helpful in addressing them. A fourth survey question was designed to discover the issues facing Korean chaebols.

The five important issues facing Korean chaebols (improving management, establishing business transparency, innovations in chaebols organization, new technology development, and reducing conflicts and establishing cooperation between labor and management) are related to the shortcomings of chaebols in Table 3. Perhaps the most pressing issue from the owners' perspectives today is the transition of ownership from parents to children. As owners of chaebols age and try to find ways to transfer ownership and management to children, these efforts waste entrepreneurs' talents and are not productive (Baumol, 1990; Murphy et al., 1991). Policy makers and Korean society need to find ways to reduce these wastes. Expert managers also accompany hazards. Hired managers with small ownership stakes generate large agency costs as seen in the U.S. corporations.

Table 4: Issues facing Korean Chaebols

\begin{tabular}{|c|c|c|c|c|c|}
\hline \multirow{2}{*}{ Factors } & \multicolumn{5}{|c|}{ Responses } \\
\hline & 1 & 2 & 3 & Total & Rank \\
\hline Improving management & 47 & 42 & 24 & 249 & 1 \\
\hline Establishing transparency & 25 & 16 & 21 & 128 & 2 \\
\hline Innovating in chaebol organization & 12 & 26 & 38 & 126 & 3 \\
\hline Developing new technology & 15 & 24 & 19 & 112 & 4 \\
\hline $\begin{array}{c}\text { Reducing conflicts and establishing cooperation between labor } \\
\text { and management }\end{array}$ & 24 & 9 & 15 & 105 & 5 \\
\hline Maintaining international competitiveness in products & 18 & 8 & 10 & 80 & 6 \\
\hline Addressing lack of demand for products & 19 & 14 & 9 & 94 & 7 \\
\hline Coordinating growth and income distribution & 12 & 18 & 14 & 86 & 8 \\
\hline Finding skilled labor & 6 & 17 & 15 & 67 & 9 \\
\hline Dealing with excessive government intervention & 8 & 8 & 7 & 47 & 10 \\
\hline $\begin{array}{c}\text { Managing problems associated with economic growth and } \\
\text { environmental pollutions }\end{array}$ & 2 & 3 & 6 & 18 & 11 \\
\hline Other & 1 & 1 & 4 & 9 & 12 \\
\hline
\end{tabular}

Because corporate entrepreneurs play a key role in corporate innovation and firm growth, a nation's economic growth depends heavily on the firm growth. As noted by Baumol $(1968,1990)$ and Murphy et al. (1991), the productive contribution of a society's entrepreneurial activities vary depending on the relative payoffs on the types of entrepreneurial activities. To foster economic growth, society and policy makers should therefore provide an environment for productive entrepreneurial activities. Murphy et al. (1991) found that in most countries, rent seeking rewards talent more than entrepreneurship does, leading to stagnation. Therefore, a reduction in inheritance tax should be given careful attention to lower the transition costs. Public policy makers and society also need to find ways to channel the inheritance taxes to investment in R \& D to improve the chaebols' global competitiveness. 


\section{Discussions}

\subsection{Chaebols' Diversification And Its Problems}

Clearly, forms of organization matter in performances of the firm (Brickley, Smith and Zimmerman, 2007; Milgrom and Roberts, 1992). Chaebols offer some significant advantages. Teece (1982) pointed out that transaction costs, excess resources and scope economies are sources of the firm's product diversification. Here we have examined other sources of the firm's product portfolio diversification. Of course business performances vary depending on the business cycle and product life cycle. Salter and Weinhold (1979) point out that diversification combines multiple business cycles from each product market, thus lowering risk, that is, smoothing out performance fluctuations. Some products may be procyclical and others may be counter cyclical. If a firm produces a single product, the performance of the firm will change drastically based on the phases of the business cycle. Firms may be able to avoid drastic changes in performance by mixing various products in their product portfolio. Our survey results show that diversification to avoid the risk of a single product obtained the largest number of responses.

Furthermore, profits or performances of the firm may decline when the firm's product reaches its maturity or decline stage of the product life cycle. To prevent such declining profits, firms diversify their products in newly emerging products to capture profits of the emerging growth industry, using newly emerging state of the art technology. Scholars in corporate strategy and industrial organization also have studied industry effects, corporate (business group) effects and business unit (firm) effects (Chang and Singh, 2000; Chang and Hong 2002; Rumelt, 1991; Schmalensee, 1985) and found that industry effects are strong. Schmalensee (1985) argued that industry structures such as the number of firms, market share, and entry barriers in industries can affect firm performances. It is more likely that the degree of competition gets keener as the product life cycle reaches maturity or decline, increasing the probability of low profits of the firm.

It also appears that the oligopolistic behavior of chaebols adds a significant motive for firm diversification. Significant numbers of respondents indicate that chaebols diversify to compete with other chaebols. Furthermore, large firms' decision to maximize are interdependent, as each firm speculates on the reactions of other firms in the industry (Caves, 1972; Hymer 1970, 1976).

Diversification for the purpose of an inheritance to children is not as strong as the other three factors discussed above; nevertheless it must not be totally ignored. The survey results indicate that the family ties are strong in Korean chaebols and inheritance considerations are likely to be more important for the owners of chaebols. When high inheritance taxes cause entrepreneurs to engage in non productive unlawful activities in corporate succession, chaebols will be less productive, leading to slower economic growth.

Because chaebols are well-established business groups, they enjoy better recognized brand names than newly starting firms. Brand names are intangible resources and can be utilized without being depleted as they were used in new businesses (Caves, 1980; Schmalensee, 1982). Schmalensee (1982) points out that late entrants are disadvantaged relative to pioneering brands for experience goods. Therefore, diversification is easier for chaebols than non-chaebol firms. Scale and scope economies are advantages of chaebols. Knowledge and experience in different products are advantageous in adapting changing environments.

However, chaebols also create difficulties. Shortcomings of chaebols are primarily in management costs. Coase (1937) classified the firm's costs into management cost, factor costs and transaction costs, arguing that management and transaction costs are likely to increase as a firm produces more internally rather than buying from markets. Sako (1992) indicated that interscale wage differentials between large and small firms in Japan caused increased subcontracting (outsourcing) during the ' $60 \mathrm{~s}$ in Japan. Increasing wages compared to productivity (Park, 2000) in high income countries is reason that multinational firms move their production to lower income countries. Korean Chaebols experience high management costs and wages which make them less competitive in global markets. 
The lack of transparency of chaebols leads to problems of cross-subsidy, transfer pricing and self-dealing. These problems increase exit costs and inefficiency of chaebols. The owner and manger's 'imperialistic management' in Korean chaebols have generated mixed experiences. Hanra, Haetae, Jinro and Ssangyong diversified to areas in which they did not have competencies and collapsed in the 1997 economic crisis. On the other hand, recent strong surges in telecommunication and electronics have contributed to the owner and manager's commitment to financial support for research and development.

Issues facing Korean chaebols confirm the problems of management and need to be addressed for chaebols to be more competitive. The chaebol form of business organization has advantages and shortcomings as discussed above. A test of chaebols became real in the 1997 economic crisis. Several chaebols were dissolved and changed ownership. For example, Daewoo groups, one of the big four chaebols before the crisis, became several independent single firms. Four units of the former Daewoo chaebols now belong to the top 50 businesses in Korea. This is evidence that the 1997 economic crisis and learning forced Korean chaebols to adapt to rapidly changing global markets. As a result they gained global competitiveness.

\section{Conclusions And Implications}

Traditional firm diversification theories study why, where and what of diversification. We have focused our study on why Korean chaebols are diversifying, issues facing chaebols, and chaebols` reforms after the 1997 economics crisis.

Researchers on firm diversification advocate that firms' sources of diversification are transaction cost, excess resources and scope economies. This study attempted to investigate other sources of chaebols` diversification in Korea. According to our Korean business firm survey Korean chaebols are diversifying to avoid risks stemming from a single product business, to participate in new business using newly emerging state of art technologies, and to compete with other chaebols. These three factors have not been well studied in firm diversification research, but scholars in firm diversification need to pay attention to these factors.

Korean chaebols enjoy brand name recognition for their diversification, scale and scope economies, and accumulated knowledge and experiences in many business fields. However, Korean chaebols suffer from lack of business transparency, the CEO's autocratic decision making and increasing exit cost by cross-subsidy among firms within a chaebol. The primary issue facing Korean chaebols can be characterized as a management problem stemming from the complex nature of chaebols. Managerial and entrepreneurial roles have become crucial inputs in modern business corporation success as well as a nation's economic growth. Therefore, Korean chaebols' successful management is essential for the successes of chaebols as well as for Korean economic growth.

We conclude that it is worthwhile for policy makers and scholars to pay attention to Korean chaebols' diversification and their dynamic capabilities. Korean chaebols also need to foster the advantages of chaebols and address shortcomings, particularly the problems in management, to continue to gain and to sustain competitive advantages in the global economy. Chaebols' competitive advantages will then enhance the firm, increase performance employment and expand economic growth.

\section{Acknowledgements}

We would like to express our appreciation to the Fulbright Foundation, Korea Economic Research Institute (KERI) and Saginaw Valley State University for their financial support for this research.

\section{References}

1. Ahmadjian, Christina L. and James R. Lincoln. (2001). Keiretsu, governance, and learning: case studies in change form the Japanese automotive industry, Organization Science, 9 (6), 683-701.

2. Barney, Jay B. (1986). Types of competition and the theory of strategy; toward an integrative framework, Academy of Management Review, 11 (4), 791-800. 
3. Baumol, William J. (1968). Entrepreneurship in economic theory, The American Economic Review, 58 (2), 64-71.

4. Baumol, William J. (1990). "Entrepreneurship: productive, unproductive and destructive, Journal of Political Economy, 98 (5), 893-921.

5. Brickley, James A., Clifford Smith, Jr. and Jerold Zimmerman. (2007). Managerial economics and organizational architecture, New York: McGraw Hill/Irwin, 304-477.

6. Caves, Richard E. (1971). International corporations: The industrial economics of foreign investment, Economica, 1-27.

7. Caves, Richard E. (1972). Industrial organization in economic analysis and multinational enterprise, Dunning J.H. (ed.), London: George Allen \& Unwin, 115-146.

8. Caves, Richard E. (1980). Industrial organization, corporate strategy and structure, Journal of Economic Literature, 18, 64-92.

9. Chandler, Jr., Alfred D. (1990).Scale and scope: The dynamics of industrial capitalism, Cambridge: The Belknap Press of Harvard University Press.

10. Chandler, Jr., Alfred D. (1990). Scale and scope: The dynamics of industrial capitalism, (Cambridge, MA: Harvard University Press).

11. Chang, Se-Jin and Harbir Singh. (2000). Corporate and industry effects on business unit competitive position, Strategic Management Journal, 23, 25-274.

12. Change, Se-Jin and Jaebum Hong. (2002). How much does the business group matter in Korea? Strategic Management Journal, 23, 265-274.

13. Coase, Ronald. (1937). The nature of the firm, Economica, 4, 356-405.

14. Donaldson, Lex. (2000). Organizational portfolio theory: performance-driven organizational change, Contemporary Economic Policy, 18 (4) 386-396.

15. Gorecki, Paul K. (1975). An Inter-industry analysis of diversification in the U.K. manufacturing sector, The Journal of Industrial Economics, 24(12), 131-146.

16. Grant, Robert M. (1996). Toward a knowledge-based theory of the firm, Strategic Management Journal, 17, 109-122.

17. Jung, Buyng Hue and Young Seek Yang. (1992). Economic analysis of Korean chaebol, Seoul: Korea Development Institute.

18. Hymer S.H. (1970). The efficiency of Multinational corporations, American Economic Review, 60, 441448.

19. Hymer S.H. (1976). The international operations of national firms: A study of direct foreign investment, Cambridge, MA: MIT Press.

20. Khanna, Tarun and Jan W. Rivkin. (2001). Estimating the Performance Effects of Business Groups in Emerging Markets, Strategic Management Journal, 22, 45-74.

21. Knudsen, Christian. (1995). Toward a knowledge-based theory of the firm, Strategic Management Journal, $17,109-122$.

22. Milgrom: P., and John Roberts (1992). Economics, Organization and Management, Englewood: Prentice Hall, Inc.

23. Montgomery, Cynthia A. and Birger Wernerfelt. (1988). Diversification, Richardian Vents, and Tobin's q, Rand Journal of Economics, 19 (4), 623-632.

24. Murphy, K.M., A. Shleifer and R. Vishny. (1991). the allocation of talent: implications for growth, The Quarterly Journal of Economics, 106 (2)503-530.

25. Nelson, Richard P., and Sidney G. Winter. (1982). An Evolutionary Theory of Economic Change, Cambridge: Belknap Press.

26. Nonaka, I., and H. Takeuohi. (1995). The Knowledge-creating Company: How Japanese Companies Create the Dynamics of Innovation, Oxford, U.K.: Oxford University Press.

27. Park, Hong Y., C.S. Reddy, G.C. Shin and C. Eckerle. (1996). Impact of the supplier certification program in U.S. Firms, European Journal of Purchasing \& Supply Management, 2 (2/3), 107-118.

28. Park, Hong Y. (2000). Foreign direct investment and global sourcing choices of firms in the U.S., Managerial and Decision Economics, 21, 211-221.

29. Park, Hong Y. and Geon-Cheol Shin. (2004). The Unified Theory of the Firm and Corporate Strategies: Measures to Build Corporate Competitiveness, Seoul, Korea: Korean Economic Research Institute (KERI). 
30. Pavitt, K., M. Robinson and J. Townsend.(1989). Technological accumulation, diversification, and organization of U.K. companies, 1945-1983, Management Science, 35, (1), pp.

31. Penrose, Edith T. (1959). The theory of the growth of the firm, New York: Wiley Inc.

32. Rumelt, Richard P. (1982). Diversification Strategy and Profitability, Strategic Management Journal, 3 , 359-369.

33. Rumelt, Richard P. (1991). How much does industry matter? Strategic Management Journal, 12, 167-185.

34. Sako, Mary. (1992). Prices, Quality and Trust: Inter-firm Relations in Britain and Japan, Cambridge, U.K.: Cambridge University Press.

35. Salter, Malcolm S., and Wolf A. Weinhold. (1979). Diversification through Acquisition: Strategies for Creating Economic Value, New York: Free Press.

36. Schmalensee, Richard. (1982). Product differentiation advantages of pioneering brands, American Economic Review, 72, 349-365.

37. Schmalensee, Richard. (1985). Do markets differ much? American Economic Review, 75 (3), 341-351.

38. Simon Herbert A. (1993). Strategy and organizational evolution, Strategic Management Journal, 14, 131142.

39. Spencer, J.C. (1996). Making knowledge the basis of a dynamic theory of the firm, Strategic Management Journal, 17, (Winter special issue), 45-52.

40. Teece, David J. and Gary Pisano. (1994).The dynamic capabilities of firms: an introduction, Industrial and Corporate Change, 3 (3), 537-556.

41. Teece, David J. (1980). Economies of Scale and the Scope of the Enterprise, Journal of Economic Behavior and Organization, 1, 223-247.

42. Teece, David J. (1982). An economic theory of multiproduct firms, Journal of Economic Behavior and Organization, 3, 39-63.

43. Teece, David, Richard Rumelt, Giovanni Dosi and Sidney Winter. (1994). Understanding corporate coherence: theory and evidence, Journal of Economic Behavior and Organization, 23, 1-30.

44. Williamson, Oliver E., (1985). The economic intuition of capitalism, New York: Free Press.

45. Williamson, Oliver E. (1975). Markets and hierarchies: analysis and antitrust implications, New York: Free Press.

\section{NOTES}


NOTES 